\title{
The reversal sign
}

\author{
Daniel Gaete, ${ }^{1}$ Antonio Lopez-Rueda ${ }^{2}$
}

${ }^{1}$ Clinica Alemana de Santiago, Santiago, Chile ${ }^{2}$ Hospital Clinic i Provincial de Barcelona, Barcelona, Spain

\section{Correspondence to} Antonio Lopez-Rueda, alrueda81@hotmail.com

Accepted 18 April 2014

\section{(a) CrossMark}

To cite: Gaete D, LopezRueda A. BMJ Case Rep Published online: [please include Day Month Year] doi:10.1136/bcr-2014204419

\section{DESCRIPTION}

A 75 -year-old man with a history of chronic obstructive pulmonary disease was found in cardiopulmonary arrest. After successful resuscitation the patient was transferred to our institution. On arrival, a non-enhanced brain CT was performed to assess brain damage, which showed signs of diffuse cerebral oedema, with effacement of the cerebral sulci, sulcal hyperdensity and decreased attenuation of deep and cortical grey matter which appears hypodense in comparison to the white matter, a finding referred to as the 'reversal sign' (figures 1 and 2). These injuries were secondary to global brain ischaemia. In less than $8 \mathrm{~h}$, the patient developed multiple organ dysfunction syndrome and was pronounced dead.

Cardiopulmonary arrest may lead to diffuse hypoxic ischaemic brain injury. Initially, unenhanced brain CT may show subtle hypodensity of the basal ganglia and insular cortex, with effacement of the basal cisterns. When diffuse brain oedema develops, the findings become more obvious, with effacement of the sulci and cisterns, and loss of the grey matter-white matter differentiation. The features of the so-called reversal sign are diffusely decreased density of cerebral cortical grey matter relative to adjacent white matter, which appears hyperdense, resulting in inversion of the normal attenuation relationship between grey and white matter. ${ }^{12}$ This, may or may not coexist with an increased attenuation of the thalami, brainstem and cerebellum, also known as preservation of central structures. $^{2}$

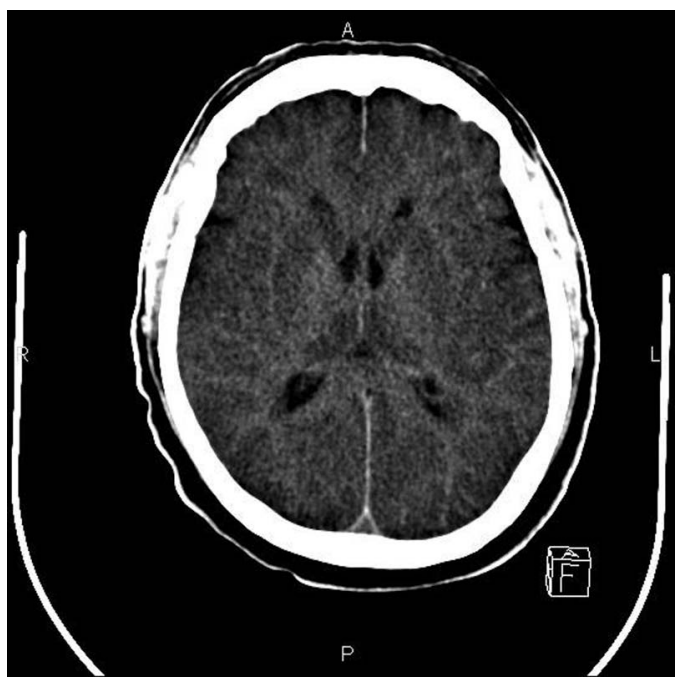

Figure 1 Axial unenhanced CT showing effacement of the sulci and deep grey matter hypodensity. Notice the loss of cortical grey matter-white matter differentiation, with inversion of the normal attenuation pattern, the so-called reversal sign.

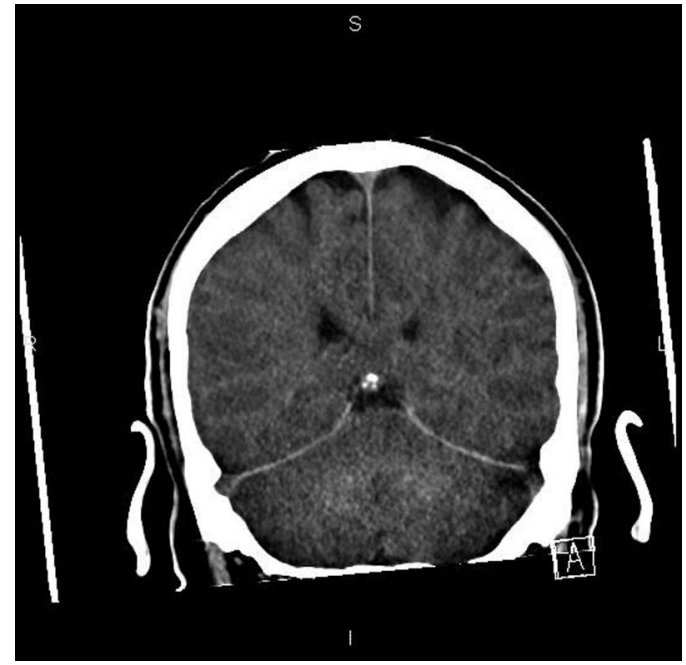

Figure 2 Coronal reformatted image of the same patient showing the reversal sign, which is also present in the cerebellum.

The reversal sign reflects a diffuse hypoxic ischaemic cerebral injury, with irreversible brain damage, which carries a poor prognosis. ${ }^{13}$

\section{Learning points}

- Many different conditions may lead to hypoxic ischaemic brain injury in children and adults.

- Loss of the grey matter-white matter differentiation is a frequent finding in patients with diffuse brain oedema, but sometimes the decreased density of the cortical and deep grey matter with inversion of the normal attenuation pattern of the brain, might give a wrong impression of normality.

- Reversal sign is associated with severe and irreversible brain damage, which carries a poor prognosis.

Contributors The authors contributed to the conception and design of the work, revised the document and images critically and gave the final approval of the version to be published.

Competing interests None.

Patient consent Obtained.

Provenance and peer review Not commissioned; externally peer reviewed.

\section{REFERENCES}

1 Kavanagh E. The reversal sign. Radiology 2007;245:914-15.

2 Chen $C$. Central structure preservation of the reversal sign. Neuroradiology 1999;41:946-8.

3 Han B, Towbin R, De Courten-Myers G, et al. Reversal sign on CT: effect of anoxic/ischemic cerebral injury in children. $A m ~ J$ Neuroradiol 1989:10:1191-8. 


\section{Images in...}

Copyright 2014 BMJ Publishing Group. All rights reserved. For permission to reuse any of this content visit http://group.bmj.com/group/rights-licensing/permissions.

BMJ Case Report Fellows may re-use this article for personal use and teaching without any further permission.

Become a Fellow of BMJ Case Reports today and you can:

- Submit as many cases as you like

- Enjoy fast sympathetic peer review and rapid publication of accepted articles

- Access all the published articles

- Re-use any of the published material for personal use and teaching without further permission

For information on Institutional Fellowships contact consortiasales@bmjgroup.com

Visit casereports.bmj.com for more articles like this and to become a Fellow 